\title{
Substrates and temperatures in the germination of Eriotheca gracilipes seeds ${ }^{1}$
}

\author{
Substratos e temperaturas na germinação de sementes de Eriotheca gracilipes
}

\section{Paulo Alexandre Fernandes Rodrigues de Melo ${ }^{2 *}$, Maria Idaline Pessoa Cavalcanti ${ }^{3}$, Edna Ursulino Alves ${ }^{4}$, Cibele Chalita Martins ${ }^{2}$ and Luciana Rodrigues de Araújo ${ }^{4}$}

\begin{abstract}
The Eriotheca gracilipes (K. Schum.) A. Robyns) is a forest specie that belongs to the Bombacaceae family and is considered an endemic specie from the Brazilian savanna. The aim of this study was to evaluate the best substrate and temperature for the vigor and germination test of E. gracilipes seeds. The experiment was carried out in a randomized design with a $4 \times 7$ factorial, with 28 treatments with the combination of four temperatures $(20 ; 25 ; 30$ and $20-30{ }^{\circ} \mathrm{C}$ ) and seven substrates (coarse vermiculite, medium vermiculite, sand, Basaplant ${ }^{\circledR}$, paper towel, on and between filter papers), with 4 repetitions of 25 seeds each. It was assessed germination, first count of germination, and germination speed index. In conclusion, for germination and vigor tests of Eriotheca gracilipes seeds it is recommended the paper roll as substrate at temperatures of $20-30,25$ or $30{ }^{\circ} \mathrm{C}$, and the Basaplant ${ }^{\circledR}$ and paper roll at the temperature of $30^{\circ} \mathrm{C}$, respectively.
\end{abstract}

Key words: Bombax gracilipes. Endemic species. Native forest. Vigor.

RESUMO - A Eriotheca gracilipes (K. Schum.) A. Robyns) é uma espécie florestal pertencente à família Bombacaceae, considerada endêmica das savanas brasileiras. O objetivo deste estudo foi avaliar o melhor substrato e temperatura para o teste de germinação e vigor de sementes de E. gracilipes. Quanto ao delineamento experimental utilizado foi inteiramente casualizado, num arranjo fatorial $4 \times 7$, perfazendo 28 tratamentos, constituídos pelas combinações de quatro temperaturas $\left(20 ; 25 ; 30\right.$ e $\left.20-30{ }^{\circ} \mathrm{C}\right)$ e sete substratos (vermiculita grossa, vermiculita média, areia, Basaplant ${ }^{\circledR}$, rolo de papel toalha, sobre e entre papel de filtro), com quatro repetições de 25 sementes. Foram avaliadas as seguintes variáveis: germinação, primeira contagem e índice de velocidade de germinação. Em conclusão, para o teste de germinação e vigor de sementes de Eriotheca gracilipes, recomenda-se o substrato rolo de papel nas temperaturas de 20-30, 25 ou $30^{\circ} \mathrm{C}$, e os substratos Basaplant ${ }^{\circledR}$ e rolo de papel na temperatura de $30^{\circ} \mathrm{C}$, respectivamente.

Palavras-chave: Bombax gracilipes. Espécie endêmica. Florestal nativa. Vigor.

\footnotetext{
DOI: $10.5935 / 1806-6690.20170035$

*Autor para correspondência

Recebido para publicação em 08/09/2015; aprovado em 07/06/2016

${ }^{1}$ Parte do Trabalho de Conclusão de Curso da segunda autora apresentado no Curso de Agronomia da Universidade Federal da Paraíba/UFPB, Areia-PB, Brasil

${ }^{2}$ Programa de Pós-Graduação em Produção Vegetal, Universidade Estadual Paulista "Júlio de Mesquita Filho", via de acesso Prof. Paulo Donato Castellane s/n, Jaboticabal-SP, Brasil, 14.884-900, pauloalexandrefernandes@outlook.com, cibele@fcav.unesp.br

${ }^{3}$ Programa de Pós-Graduação em Ciências Agrárias, Universidade Estadual da Paraíba/UEPB, Campina Grande-PB, Brasil, maria_idaline@ hotmail.com

${ }^{4}$ Departamento de Fitotecnia e Ciências Ambientais/CCA-UFPB, Campus II, Areia-PB, Brasil, ednaursulino@cca.ufpb.br, lraraujo1@yahoo.com.br
} 


\section{INTRODUCTION}

Eriotheca gracilipes (K. Schum.) A. Robyns is an endemic specie present only in the brazilian savanna (MENDES-RODRIGUES; RANAL; OLIVEIRA, 2011), in reforestation areas of the Amazon forest, caatinga and semi-deciduous seasonal forest in the northern, northeastern and southeastern states of Brazil (LONGUI et al., 2012), popularly known as imbiru, bingueiro and embiruçu. It is a semi-deciduous tree reaching 4-17 $\mathrm{m}$ of height and with a flowering period from May to September. The fructification period is between the months of September and October, with dehiscence fruit from the capsule type. The seeds have light brown coloration (SILVA, 2007), and are wrapped by a fiber and dispersed by the wind (MENDES-RODRIGUES; RANAL; OLIVEIRA, 2011), common on the diet of birds such as parrots, parakeets and macaws, which can make difficult the availability of seeds in anthropized ecosystems and the natural regeneration for future conservation purposes (RAGUSA-NETTO, 2014).

The germination test is the most important parameter used to assess the seeds physiological quality and allows the knowledge of the germination potential of lot and the results are very useful to determine the seedlings rate of production (MARTINS; MACHADO; NAKAGAWA, 2008). However, for almost all native species, the methodology of the test has not been established for factors such as substrate and temperature (MARTINS et al., 2012).

For Brazilian subtropical forest species the optimum temperature zone is between $20-35{ }^{\circ} \mathrm{C}$ since these are temperatures are observed in the plants regions of origin, at the correct time for the natural germination (ANDRADE et al., 2006; MARTINS; MACHADO; NAKAGAWA, 2008). Beyond the substrate temperature, the germination is also influenced by structure, air space, water retention capacity, pathogen infestation level and other factors that can influence the seed germination. The substrate represents the physical support upon which the seed is placed with the function of offering and preserving the appropriate conditions of seed germination and seedling growth (MARTINS et al., 2013).

Thus, the choice of the substrate should be based on the seeds needs, substrate type and form (ALVES et al., 2011). So, for some seeds of forestry species the definition of an ideal substrate has been already established as for example C. glaziovii that should be sowed with sand or with the aid of paper rolls (GUEDES; ALVES, 2011), while other seed species, such as Pseudobombax grandiflorum (Cav.) A. Robyns) and Pseudobombax longiflorum (Mart. et Zucc.) A. Robyns), are more adapted and able to germinate in other substrates and are recommended to be sowed on sand and vermiculite (LADEIA et al., 2012).
Therefore, considering the importance of the temperature and substrate for seed germination, the aim of this study was to evaluate the best substrate and temperature for the germination and vigor tests of $E$. gracilipes seeds.

\section{MATERIALS AND METHODS}

The current study was developed using $E$. gracilipes seeds, which were harvested from mature fruits from 10 mother plants located at Areia, county of the state of Paraiba, Brazil during the month of April, 2013. After harvest, the fruits were packed in polyethylene bags and taken to the Laboratory of Seed Analysis (LAS) of the Department of Plant and Environmental Sciences, Agricultural Science Center of the Federal University of Paraiba. Fruits were collected just before capsule dehiscence and were stored at room temperature $\left(25-30{ }^{\circ} \mathrm{C}\right)$ and in shade until opening. The seeds were obtained through the manual processing, which consisted of the removal of the fiber that covers the seed and then the initial moisture content was evaluated by the oven method at $105 \pm 3{ }^{\circ} \mathrm{C}$ for 24 hours (MENDESRODRIGUES; RANAL; OLIVEIRA, 2011). Then the seeds were homogenized and treated with Captana fungicide before the experiments. Fruits that opened 3 days after collection were used to avoid immature seeds.

The vigor evaluation was performed in germination chambers set at constant temperatures of 20, 25, 30 and an alternated temperatures of $20-30{ }^{\circ} \mathrm{C}$ and $12 \mathrm{~h}$ light/12 h dark, using fluorescent lamps (20W $\mathrm{x} 4$ ). Four replications of 25 seeds were sown between moist substrates of coarse and medium vermiculite, sand, Basaplant ${ }^{\circledR}$, two filter sheets (placed between and over the sheets), distributed in transparent plastic boxes $(11,0 \times 11,0 \times 3,5 \mathrm{~cm})$ and also in paper rolls. Readings were taken through daily counts of normal germinated seedlings during 21 days after sowing (ALVES et al., 2011; BRASIL, 2009). Final results were expressed in percentage.

The vigor of $E$. gracilipes seeds was determined by the first count of germination (FCG), held at the same time with the germination test, calculating the average number of seeds germinated on the fifth day after sowing. The germination speed index (GSI) was also determined by counting the number of normal seedlings, from 5 to 21 days after sowing, daily (MENDES-RODRIGUES; RANAL; OLIVEIRA, 2011). After the end of the germination evaluation, the seedlings were submitted to separation of roots and shoots and subsequently placed in Kraft paper bags and taken to an oven set at $65^{\circ} \mathrm{C}$ until constant weight (48 hours) in order to determine dry mass 
and, after that period, weighed on an analytical scale with an accuracy of $0.001 \mathrm{~g}$ (MARTINS et al., 2013).

The experiments were realized in a completely randomized design, with treatments arranged in a $4 \times 7$ factorial, the first factor represented by the temperatures and the second by the substrates, with four repetitions. The data were submitted to variance analysis using the $\mathrm{F}$ test to compare the mean squares and the means were compared according to Scott-Knott's test at $5 \%$ of probability.

\section{RESULTS AND DISCUSSION}

The higher germination percentages of $E$. gracilipes seeds (Table 1) were achieved when the following interactions were used: temperature $20-30{ }^{\circ} \mathrm{C}$ and the substrates of coarse vermiculite, sand or paper roll, at $20{ }^{\circ} \mathrm{C}$ between paper, at $25^{\circ} \mathrm{C}$ with vermiculite, between the paper and paper roll, as well as at the alternated temperatures of $20-30{ }^{\circ} \mathrm{C}$ with the Basaplant ${ }^{\circledR}$ substrates and paper roll. For the other combinations of substrates and temperatures, the germination percentage was lower.

Through these studies, it may be inferred that the substrate and the temperature influence the seed germination, because when the germination process is started, metabolic reactions involving the activation of enzymes, hydrolysis, assimilation and mobilization of reserves, stretching and cell division are observed in the seeds (ALBUQUERQUE et al., 2009). Thus, in addition to the physiological activities that vary depending on the initial quality of the seed (MBOFUNG et al., 2013), the structure of the substrate, water retention capacity, aeration establishment and temperature also contribute to the increased percentage of germination (MARTINS et al., 2013).
In the optimum temperature is possible to achieve the highest percentage of germination in a short interval (MIJAN et al., 2013). Therefore, the obtained results suggested that the germination of $E$. gracilipes seeds, should occur, preferably, in a constant temperature of $25{ }^{\circ} \mathrm{C}$ or altered from $20-30{ }^{\circ} \mathrm{C}$ with medium vermiculite or sand as substrates, since this conditions resulted in maximum values of germination (94\% and 92\%), respectively, at 21 days (end of test), but this values were not statistically different from the treatments with the use of paper roll $\left(25^{\circ} \mathrm{C}\right)$ and Basaplant ${ }^{\circledR}\left(30{ }^{\circ} \mathrm{C}\right)$, that presented maximum values for normal seedlings germination, with the same number of days.

Looking from an economical prospective, both substrates (vermiculite and sand) are recommended for germination test because they are inexpensive, easy to use and with high availability (ALVINO; RAYOL, 2007). The significant interaction between temperature and substrate found in this study corroborate to the results found by Pereira et al. (2014), who reported the efficiency of vermiculite and sand as substrates in the germination of forest seeds.

These results are probably due to the capacity of water retention of these substrates when used together, since vermiculite has good absorption capacity and water retention, which allowed more contact with the seed, being recommended by Pilau et al. (2012) for seeds with spherical shape.

At high temperatures, the sand is not able to maintain the moisture, with better efficiency in moderate temperature due to its low retention and poor distribution of water, excessively draining with the characteristic of dry at the upper portion (ALVINO; RAYOL, 2007).

Table 1 - Germination of Eriotheca gracilipes seeds in different substrates and temperatures

\begin{tabular}{lcccr}
\hline \multirow{2}{*}{ Substrates } & \multicolumn{4}{c}{ Temperatures $\left({ }^{\circ} \mathrm{C}\right)$} \\
\cline { 2 - 5 } & $20-30$ & 20 & 25 & 30 \\
\hline Coarse vermiculite & $86 \mathrm{aA}$ & $54 \mathrm{cB}$ & $81 \mathrm{bA}$ & $86 \mathrm{~dB}$ \\
Medium vermiculite & $81 \mathrm{aB}$ & $86 \mathrm{aB}$ & $94 \mathrm{aA}$ & $93 \mathrm{aA}$ \\
Basaplant $^{\circledR}$ & $65 \mathrm{bC}$ & $73 \mathrm{bB}$ & $76 \mathrm{bB}$ & $70 \mathrm{cB}$ \\
Sand & $92 \mathrm{aA}$ & $20 \mathrm{dC}$ & $30 \mathrm{cC}$ & $80 \mathrm{bA}$ \\
On paper & $68 \mathrm{bB}$ & $73 \mathrm{bB}$ & $88 \mathrm{aA}$ & $81 \mathrm{bA}$ \\
Between paper & $42 \mathrm{cB}$ & $80 \mathrm{aA}$ & $95 \mathrm{aA}$ & $88 \mathrm{aA}$ \\
Paper roll & $89 \mathrm{aA}$ & $81 \mathrm{aB}$ & & \\
CV $(\%)$ & 8,56 & & & \\
\hline
\end{tabular}

Means followed by the lowercase letters between substrates and uppercase between the temperatures do not differ at $5 \%$ probability according to Scott-Knott's test 
These results are in agreement with those obtained by Zamith and Scarano (2006), as well as by Lopes et al. (2008) with other species from the Bombacaceae family, where the maximum germination percentage (95\%) was observed for Pseudobombax grandiflorum (Cav.) A. Robyns. seeds that were sowed in sand substrates at the alternating temperatures of 20$30{ }^{\circ} \mathrm{C}$. In addition, it corroborated with germination results of Pseudobombax marginatum (St. Hil.) Robyns. Seeds, suggesting a temperature of $25^{\circ} \mathrm{C}$ using vermiculite as substrate to obtain higher germination values (MONDEGO et al., 2014). It also appears that the E. gracilipes seeds, according to Ruas et al. (2010), has a reduced contact area with the paper substrate (between and on) due to its spherical form, that is associated to the low fluidity at low water temperatures, hindering their passage through the integument, which could explain the reduction in efficacy of this substrate at $20^{\circ} \mathrm{C}$.
The best physiological performance of $E$. gracilipes seeds, measured through the first count of germination (Table 2) and germination speed index (Table 3) were associated to the interaction between substrates and coarse vermiculite at $30{ }^{\circ} \mathrm{C}$, for both evaluated factors, although not statistically different from the GSI evaluated at the same temperature on sand and Basaplant ${ }^{\circledR}$ substrates. No statistical differences were observed for the results cited above for the seeds with the use of paper roll at temperatures of 20-30, 20 and $25^{\circ} \mathrm{C}$ on the FCG and GSI in this same substrate, regardless the temperature.

Differences regarding the ideal thermal condition for the germination tests of $E$. gracilipes seeds (Tables 1, 2 and 3) are explained by the fact that the optimum temperature for higher uniformity and germination rate is always higher than the ideal temperature for the

Table 2 - First count of germination at 5 days of Eriotheca gracilipes seeds for different substrates and temperatures

\begin{tabular}{lcccc}
\hline \multirow{2}{*}{ Substrates } & \multicolumn{4}{c}{ Temperatures $\left({ }^{\circ} \mathrm{C}\right)$} \\
\cline { 2 - 5 } & $20-30$ & 20 & 25 & 30 \\
\hline Coarse vermiculite & $86 \mathrm{aA}$ & $54 \mathrm{cB}$ & $81 \mathrm{bA}$ & $58 \mathrm{~dB}$ \\
Medium vermiculite & $81 \mathrm{aB}$ & $86 \mathrm{aB}$ & $94 \mathrm{aA}$ & $86 \mathrm{aB}$ \\
Basaplant $^{\circledR}$ & $65 \mathrm{bC}$ & $73 \mathrm{bB}$ & $76 \mathrm{bB}$ & $93 \mathrm{aA}$ \\
Sand & $92 \mathrm{aA}$ & $20 \mathrm{dC}$ & $30 \mathrm{cC}$ & $70 \mathrm{cB}$ \\
On paper & $68 \mathrm{bB}$ & $73 \mathrm{bB}$ & $88 \mathrm{aA}$ & $80 \mathrm{bA}$ \\
Between paper & $42 \mathrm{cB}$ & $80 \mathrm{aA}$ & $95 \mathrm{aA}$ & $88 \mathrm{aA}$ \\
Paper roll & $89 \mathrm{aA}$ & $81 \mathrm{aB}$ & & \\
CV $(\%)$ & 8,56 & & & \\
\hline
\end{tabular}

Means followed by the same lowercase letters between substrates and uppercase between the temperatures do not differ at $5 \%$ of probability according to Scott-Knott's test

Table 3 - Germination speed index of Eriotheca gracilipes seeds for different substrates and temperatures

\begin{tabular}{lcccc}
\hline \multirow{2}{*}{ Substrates } & \multicolumn{4}{c}{ Temperatures $\left({ }^{\circ} \mathrm{C}\right)$} \\
\cline { 2 - 5 } & $20-30$ & 20 & 25 & 30 \\
\hline Coarse vermiculite & $2,79 \mathrm{bB}$ & $1,50 \mathrm{cC}$ & $3,10 \mathrm{bB}$ & $3,56 \mathrm{aA}$ \\
Medium vermiculite & $2,40 \mathrm{cB}$ & $2,39 \mathrm{bB}$ & $2,32 \mathrm{bA}$ & $3,59 \mathrm{aA}$ \\
Basaplant $^{\circledR}$ & $1,80 \mathrm{dC}$ & $1,65 \mathrm{cC}$ & $2,31 \mathrm{cB}$ & $3,46 \mathrm{aA}$ \\
Sand & $2,13 \mathrm{cC}$ & $1,17 \mathrm{cD}$ & $2,74 \mathrm{cB}$ & $3,35 \mathrm{aA}$ \\
On paper & $1,89 \mathrm{~dB}$ & $1,95 \mathrm{bB}$ & $2,50 \mathrm{cA}$ & $2,96 \mathrm{bA}$ \\
Between paper & $1,43 \mathrm{~dB}$ & $2,21 \mathrm{bA}$ & $3,39 \mathrm{cA}$ & $2,75 \mathrm{bA}$ \\
Paper roll & $3,55 \mathrm{aA}$ & $3,58 \mathrm{aA}$ & $3,77 \mathrm{aA}$ & $3,51 \mathrm{aA}$ \\
CV $(\%)$ & 13,46 & & & \\
\hline
\end{tabular}

Means followed by the same lowercase letters between substrates and uppercase between the temperatures do not differ at 5\% of probability according to Scott-Knott's test 
total germination, according to Martins et al. (2013), when studding the effect of temperature and substrate on Fimbristylis dichotoma (L.) Vahl. seeds germination. Higher temperatures favors the water absorption and the biochemical reactions in the early stages of germination, within certain limits, which could increase the uniformity and germination speed. However, during the germination process, temperatures above the optimal enzymatic metabolism may have a negative effect, so the number of seeds capable to complete the total germination process rapidly decreases, increasing the number of abnormal seedlings and dead seeds (MARTINS et al., 2013).

The results obtained in this study are consistent with those reported by Martins, Machado and Nakagawa (2008), who evaluated the Stryphnodendron adstringens ((Mart.) Coville) seed germination at different temperatures and substrates, which concluded that for this species the biggest speed and uniformity of germination (FCG) was possible achieved using paper as a substrate and at $30^{\circ} \mathrm{C}$. Similar results were also associated with GSI obtained by Lopes et al. (2008), who evaluated the physiological quality of $P$. grandiflorum seeds sown in vermiculite and sand and also with those found by Mondego et al. (2014), in which is possible to observe that the most rapid and uniform germination of $P$. marginatum occurred when vermiculite was used as substrate.

Similarly, the use of vermiculite, sand and paper roll for the analysis influenced positively the $E$. gracilipes seed germination, with greater uniformity and speed of germination, regardless the temperature. Similarly, Barbosa et al. (2004) studying other species from the Bombacaceae family, such as Ochroma lagopus Sw. and Lopes et al. (2008) with P. grandiflorum found that the substrate paper are indicated in the evaluation of seeds physiology quality. Consequently, the speed and uniformity of germination are desirable characteristics, since the longer the seedling remains in the early stages of development, more it will be submitted to adverse environmental conditions, including susceptible to fungi (MARTINS et al., 2012), frequently present in covered seed by the fibers (MONDEGO et al., 2014).

According to the results, it was observed that only the Basaplant ${ }^{\circledR}$ substrate provided higher dry matter content of E. gracilipes seedlings shoot at $30{ }^{\circ} \mathrm{C}$ (Table 4). On the other hand, the constant temperature of $20^{\circ} \mathrm{C}$ on sand substrate caused a reduction up to $34 \mathrm{~g}$ plant $^{-1}$ of dry mass on average in comparison to the higher average of $35 \mathrm{~g} \mathrm{plant}^{-1}$ (Basaplant ${ }^{\circledR}$ at $30^{\circ} \mathrm{C}$ ), showing that different temperatures have different effects on dry matter accumulation of E. gracilipes seedlings.

For the root dry mass (Table 5) the best results were obtained with the use of coarse vermiculite substrates at the temperature of $20-30{ }^{\circ} \mathrm{C}$, paper roll at temperatures of 20 to $30^{\circ} \mathrm{C}$ and the sand substrate at $25^{\circ} \mathrm{C}$. Similar results were obtained by Mendes-Rodrigues, Ranal and Oliveira (2011), studying polyembryony of Eriotheca pubescens (Mart. Former Zucc.) Schoutt \& Endler and E. gracilipes seeds, when the higher biomass allocation in the roots of the germinated seedlings were observed with the use of sand at $25^{\circ} \mathrm{C}$. The same was observed by Silva (2007) in studies with Adenanthera pavonina L. seedlings, which found the highest dry mass content using the vermiculite substrate at $20-30{ }^{\circ} \mathrm{C}$.

It was also found that the Basaplant ${ }^{\circledR}$ substrates (Table 4), sand and vermiculite (Table 5), may provide better conditions for rooting due to an increase in aeration capacity, providing a better development of aerial part, and if good root system is formed, the plant will develop

Table 4 - Aerial part dry mass of Eriotheca gracilipes seedlings grown from seeds submitted to different substrates and temperatures, collected 21 days after sowing

\begin{tabular}{lcccc}
\hline \multirow{2}{*}{ Substrates } & \multicolumn{4}{c}{ Temperatures $\left({ }^{\circ} \mathrm{C}\right)$} \\
\cline { 2 - 5 } & $20-30$ & 20 & 25 & 30 \\
\hline Coarse vermiculite & $14 \mathrm{bA}$ & $8 \mathrm{bB}$ & $17 \mathrm{cA}$ & $15 \mathrm{eA}$ \\
Medium vermiculite & $19 \mathrm{aC}$ & $12 \mathrm{aD}$ & $24 \mathrm{aB}$ & $30 \mathrm{bA}$ \\
Basaplant $^{\circledR}$ & $17 \mathrm{aC}$ & $11 \mathrm{aD}$ & $25 \mathrm{aB}$ & $35 \mathrm{aA}$ \\
Sand & $11 \mathrm{bB}$ & $1 \mathrm{dC}$ & $11 \mathrm{eB}$ & $17 \mathrm{dA}$ \\
On paper & $8 \mathrm{cB}$ & $4 \mathrm{cC}$ & $10 \mathrm{eB}$ & $17 \mathrm{dA}$ \\
Between paper & $7 \mathrm{cB}$ & $8 \mathrm{bB}$ & $14 \mathrm{dA}$ & $13 \mathrm{eA}$ \\
Paper roll & $21 \mathrm{aB}$ & $12 \mathrm{aC}$ & $21 \mathrm{bB}$ & $25 \mathrm{cA}$ \\
CV $(\%)$ & 14,35 & & & \\
\hline
\end{tabular}

Means followed by the same lowercase letters between substrates and uppercase between the temperatures do not differ at $5 \%$ of probability by Scott-Knott's test 
Table 5 - Root dry mass of Eriotheca gracilipes seedlings from seeds submitted to different substrates and temperatures, 21 days after sowing

\begin{tabular}{lcccc}
\hline \multirow{2}{*}{ Substrates } & \multicolumn{4}{c}{ Temperatures $\left({ }^{\circ} \mathrm{C}\right)$} \\
\cline { 2 - 5 } & $20-30$ & 20 & 25 & 30 \\
\hline Coarse vermiculite & $14 \mathrm{aA}$ & $10 \mathrm{aB}$ & $14 \mathrm{cA}$ & $12 \mathrm{aB}$ \\
Medium vermiculite $^{*}$ & $11 \mathrm{bB}$ & $14 \mathrm{aB}$ & $19 \mathrm{bA}$ & $11 \mathrm{aB}$ \\
Basaplant $^{\circledR}$ & $11 \mathrm{bC}$ & $8 \mathrm{aD}$ & $22 \mathrm{aA}$ & $13 \mathrm{aB}$ \\
Sand & $9 \mathrm{bB}$ & $3 \mathrm{bB}$ & $15 \mathrm{cA}$ & $12 \mathrm{aB}$ \\
On paper & $10 \mathrm{bB}$ & $11 \mathrm{aB}$ & $18 \mathrm{bA}$ & $12 \mathrm{aB}$ \\
Between paper & $13 \mathrm{aB}$ & $11 \mathrm{aB}$ & $14 \mathrm{cA}$ & $11 \mathrm{aA}$ \\
Paper roll & $11 \mathrm{bA}$ & $11 \mathrm{aA}$ & & \\
CV $(\%)$ & 12,15 & & & \\
\hline
\end{tabular}

Means followed by the same lowercase letters between substrates and uppercase between the temperatures do not differ at $5 \%$ of probability according to Scott-Knott's test

better (PASQUAL et al., 2000). This fact may explain best results related to root and shoot dry mass of E. gracilipes seedlings with the use of this substrate.

However, for most seeds of native forests in Brazil the procedures for the germination test are not yet standardized by the Seed Analysis Manual (MARTINS et al., 2012), which is a publication that regulates the methodology of this test, including the substrate recommendations and temperatures that should be used in order to obtain better results. Therefore, according to the results obtained in this study for E. gracilipes seeds, the standardization of the germination test under controlled laboratory conditions is appropriate to the use roll paper as substrate with temperatures of $20-30,20$ and $25^{\circ} \mathrm{C}$.

\section{CONCLUSIONS}

For germination and vigor tests of Eriotheca gracilipes seeds it is recommended the paper roll as substrate at temperatures of $20-30,25$ or $30^{\circ} \mathrm{C}$, and the Basaplant ${ }^{\circledR}$ and paper roll at the temperature of $30{ }^{\circ} \mathrm{C}$, respectively.

\section{REFERENCES}

ALBUQUERQUE, K. S. et al. Alterações fisiológicas e bioquímicas durante a embebição de sementes de sucupirapreta (Bowdichia virgilioides Kunth.). Revista Brasileira de Sementes, v. 31, n. 1, p. 12-19, 2009.

ALVES, E. U. et al. Effect of temperature and substrate on germination of Peltophorum dubium (Sprengel) Taubert seeds. Acta Scientiarum. Biological Sciences, v. 33, n. 1, p. 113-118, 2011.
ALVINO, F. O. de; RAYOL, B. P. Efeito de diferentes substratos na germinação de Ochroma pyramidale (Cav. ex Lam.) Urb. (Bombacaceae). Ciência Florestal, v. 17, n. 1, p. 71-75, 2007.

ANDRADE, A. C. S. de et al. Germinação de sementes de Dalbergia nigra (Vell.) Fr. All. Ex Benth: substrato, temperatura e desenvolvimento pós-seminal. Pesquisa Agropecuária Brasileira, v. 41, n. 3, p. 517-523, 2006.

BARBOSA, A. P. et al. Tecnologia alternativa para a quebra de dormência das sementes de pau-de-balsa (Ochroma lagopus Sw., Bombacaceae). Acta Amazonica, v. 34, n. 1, p. 107-110, 2004.

BRASIL. Ministério da Agricultura, Pecuária e Abastecimento. Secretaria de Defesa Agropecuária. Regras para Análise de Sementes. Brasília: MAPA/ACS, 2009. 395 p.

GUEDES, R. S.; ALVES, E. U. Substrates and temperatures for the germination test of Chorisia glaziovii (O. Kuntze) seeds. Cerne, v. 17, n. 4, p. 525-531, 2011.

LADEIA, E. S. et al. Procedência do fruto e substratos na germinação de sementes de Pseudobombax longiflorum (Mart. et Zucc.) A. Robyns. Pesquisa Agropecuária Tropical, v. 42, n. 2, p. 174-180, 2012.

LONGUI, E. L. et al. Root-branch anatomical investigation of Eriotheca gracilipes young trees: a biomechanical and ecological approach. Scientia Forestalis, v. 40, n. 93, p. 23-33, 2012.

LOPES, J. C. et al. Germinação de sementes de embiruçu (Pseudobombax grandiflorum (Cav.) A. Robyns) em diferentes estádios de maturação e substratos. Revista Floresta, v. 38, n. 2, p. 331-337, 2008.

MARTINS, C. C. et al. Effects of substratum, temperature, and treatments to overcome dormancy on the germination of Fimbristylis dichotoma seeds. Revista de Ciências Agrárias, v. 56, p. 44-48, 2013. Suplemento.

MARTINS, C. C. et al. Vermiculita como substrato para o teste de germinação de sementes de ipê-amarelo. Semina: Ciências Agrárias, v. 33, n. 2, p. 533-540, 2012. 
MARTINS, C. C.; MACHADO, C. G.; NAKAGAWA, J. Temperatura e substrato para o teste de germinação de sementes de barbatimão ((Stryphnodendron adstringens (Mart.) Coville (Leguminosae). Revista Árvore, v. 32, n. 4, p. 633-639, 2008.

MBOFUNG, G. C. Y. et al. Effects of storage temperature and relative humidity on viability and vigor of treated soybean seeds. Crop Science, v. 53, n. 3, p. 1086-1095, 2013.

MENDES-RODRIGUES, C.; RANAL, M. A.; OLIVEIRA, P. E. Does polyembryony reduce seed germination and seedling development in Eriotheca pubescens (Malvaceae: Bombacoideae)? American Journal of Botany, v. 98, n. 10, p. 1613-1622, 2011.

MIJAN, S. et al. Seed germination and early growth responses of hyssop, sweet Basil and oregano to temperature levels. Notulae Scientia Biologicae, v. 5, n. 4, p. 462- 467, 2013.

MONDEGO, J. M. et al. Controle alternativo da microflora de sementes de Pseudobombax marginatum com óleo essencial de copaíba (Copaifera sp.). Bioscience Journal, v. 30, n. 2, p. 349-355, 2014.

PASQUAL, M. et al. Enraizamento in vitro de um porta-enxerto de macieira em diversos substratos. Scientia Agricola, v. 57, n. 4, p. 781-784, 2000.
PEREIRA, I. M. et al. Estrutura fitossociológica da regeneração natural de uma área de cerrado no município de Curvelo, MG. Enciclopédia Biosfera, v. 10, n. 18, p. 16-19, 2014.

PILAU, F. G. et al. Germinação de sementes de crambe em diferentes temperaturas e substratos. Semina: Ciências Agrárias, v. 33, n. 5, p. 1825-1830, 2012.

RAGUSA-NETTO, J. Crop damage of Eriotheca gracilipes (Bombacaceae) by the Blue-Fronted Amazon (Amazona aestiva, Psittacidae), in the Brazilian Cerrado. Brazilian Journal of Biology, v. 74, n. 4, p. 837-843, 2014.

RUAS, R. A. A. et al. Embebição e germinação de sementes de crambe (Crambe abyssinica). Pesquisa Agropecuária Tropical, v. 40, n. 1, p. 61-65, 2010.

SILVA, P. A. da. Predação de sementes por periquitos Brotogeris chiriri (Psittacidae) em Chorisia speciosa (Bombacaceae). Revista Brasileira de Ornitologia, v. 15, n. 1, p. 127-129, 2007.

ZAMITH, L. R.; SCARANO, F. R. Produção de mudas de espécies das Restingas do município do Rio de Janeiro, RJ, Brasil. Acta Botanica Brasilica, v. 18, n. 1, p. 161-176, 2006. 